\title{
EFFECTS OF HORMONES, PROSTAGLANDINS AND CYCLIC-AMP ON THE SYNTHESIS OF PROGESTERONE BY THE HUMAN PLACENTA IN VITRO
}

\author{
J. R. BEDWANI \\ Department of Pharmacology, University of Cambridge, \\ Medical School, Hills Road, Cambridge CB2 2QD
}

\section{(Received 19th October 1972)}

It is well established that the human placenta provides the main source of progesterone after the first trimester of pregnancy. This progesterone is thought to be synthesized mainly from cholesterol present in the maternal circulation (Diczfalusy, 1969). However, little is known of the factors which control placental progesterone synthesis. The present work was carried out to see whether various hormones, and other compounds which affect steroidogenesis in other tissues, had any effect on the conversion of cholesterol to progesterone by the human placenta in vitro. The substances investigated were HCG, ovine prolactin (LTH), prostaglandin $\mathrm{E}_{1}$, which stimulates ovarian steroidogenesis in various species (Speroff \& Ramwell, 1970; Kuehl, Humes, Tarnoff, Cirillo \& Ham, 1970) and which activates human placental adenyl cyclase (Satoh \& Ryan, 1972), adrenaline, another compound which increases placental adenyl cyclase activity (Satoh \& Ryan, 1971), vasopressin, which increases plasma progesterone levels in pregnant women (Fylling, 1971), and cyclic-AMP, the proposed second messenger mediating the effects of steroidogenic hormones in other tissues. The effects of prostaglandin $F_{2 a}$, which has been detected in amniotic fluid and maternal blood during labour (Karim \& Devlin, 1967; Karim, 1968) were also investigated. This compound is effective in inducing labour (Karim, Trussell, Hillier \& Patel, 1969) and it was considered that an inhibitory effect on placental progesterone synthesis might contribute to this action.

Fresh post-partum placentae were obtained from a local maternity hospital. After birth, the placenta was placed in a beaker containing cold saline and transported to the laboratory with the minimum of delay. Small pieces were taken randomly from the placenta and cut into 200- $\mu \mathrm{m}$ slices with a McIlwain tissue chopper. The pooled slices were distributed among incubation flasks containing $20 \mathrm{ml}$ Krebs' phosphate buffer, $\mathrm{pH} 7 \cdot 4$, to which had been added human serum albumin $(250 \mu \mathrm{g} / \mathrm{ml})$, glucose-6-phosphate $(4 \mathrm{~mm})$ and NADP $(0.65 \mathrm{~mm}$ or $0.25 \mathrm{~mm})$. The medium also contained $\left[7 \alpha-{ }^{3} \mathrm{H}\right]$ cholesterol $(0.09$ to $0.45 \mu \mathrm{Ci} / \mathrm{ml})$, previously purified by thin-layer chromatography and dissolved in propylene glycol ( $1 \mathrm{ml} / 100 \mathrm{ml}$ incubation medium). The various test substances were added to the appropriate flasks. 
Incubations were carried out at $37^{\circ} \mathrm{C}$ in an atmosphere of oxygen, and terminated after 1 or $2 \mathrm{hr}$ by rapid chilling followed by the addition of $0.5 \mathrm{ml}$ $\mathrm{N}-\mathrm{NaOH}$. Known amounts of non-radioactive progesterone were added to enable measurements of recovery, and the contents of the flasks were homogenized. Progesterone was isolated by solvent extraction (Bedwani \& Marley, 1971) followed by chromatography on $0.7-\mathrm{g}$ columns of silicic acid. The columns were eluted with $2 \mathrm{ml}$ toluene followed by $16 \mathrm{ml} \mathrm{4 \%}$ ethyl acetate in toluene. This fraction contained cholesterol and was discarded. Progesterone was then eluted with $4 \mathrm{ml} 20 \%$ ethyl acetate in toluene and purified by two-dimensional thin-layer chromatography on silica gel G; the solvent systems were $n$-hexane: ethyl acetate, 5:2 and chloroform:acetone, $4: 1$.

Chromatograms were examined under ultraviolet light and the areas of silica gel containing the progesterone were eluted with $3 \mathrm{ml}$ methanol. Radioactivity in $250-\mu$ l aliquots of the eluates was counted, using a liquid scintillation spectrometer, and the progesterone content was measured spectrophotometrically.

Table 1. Radiochemical purity of $\left[{ }^{3} \mathrm{H}\right]$ progesterone isolated from human placental incubates

\begin{tabular}{|c|c|c|c|}
\hline $\begin{array}{l}\text { Crystallization } \\
\text { no. }\end{array}$ & Crystals & $\begin{array}{l}\text { Mother } \\
\text { liquor }\end{array}$ & Solvent \\
\hline 1 & $1030^{*}$ & $1200^{*}$ & \multirow{2}{*}{$\begin{array}{l}\text { Petroleum ether } \\
\text { (b.p. } 80 \text { to } 100^{\circ} \mathrm{C} \text { ): ethyl acetate, } 9: 1 \\
n \text {-Hexane:acetone, } 9: 1 \\
\text { Ethanol:water, } 7: 3\end{array}$} \\
\hline $\begin{array}{l}2 \\
3\end{array}$ & $\begin{array}{l}1085 \\
1051\end{array}$ & $\begin{array}{l}1074 \\
1101\end{array}$ & \\
\hline
\end{tabular}

* Values are specific activities ( $\mathrm{d} / \mathrm{min} / \mathrm{mg}$ progesterone). The value for the starting material was $1131 \mathrm{~d} / \mathrm{min} / \mathrm{mg}$ progesterone.

The radiochemical purity of the $\left[{ }^{3} \mathrm{H}\right]$ progesterone extracted from placental incubates by this method was checked by adding $40 \mathrm{mg}$ progesterone and recrystallizing from various solvents (Table 1).

The conversion of cholesterol to progesterone by placental slices was increased greatly by the presence of NADP in the medium. The effects of different concentrations of the nucleotide, in the presence of a fixed concentration (4 $\mathrm{mm}$ ) of glucose-6-phosphate, are shown in Text-fig. 1. In each of two experiments, maximal stimulation was observed with a concentration of $0.25 \mathrm{~mm}$.

An experiment was carried out to investigate the time course of the conversion of cholesterol to progesterone by placental slices incubated in the presence of NADP $(0.65 \mathrm{~mm})$. Incubations were carried out for up to $2 \mathrm{hr}$. After a delay of approximately $15 \mathrm{~min}$, the formation of $\left[{ }^{3} \mathrm{H}\right]$ progesterone was found to increase linearly with time for the remainder of the experiment.

The effects of the various substances investigated on the conversion of $\left[{ }^{3} \mathrm{H}\right]$ cholesterol to $\left[{ }^{3} \mathrm{H}\right]$ progesterone are shown in Table 2. Vasopressin, HCG, dibutyryl cyclic-AMP, PGF $2 x, L T H$, adrenaline and PGE $_{1}$, in the concentrations used, had no effect on the formation of $\left[{ }^{3} \mathrm{H}\right]$ progesterone, but $5 \mathrm{~mm}$-cyclic-AMP, in the presence of theophylline, reduced the conversion of cholesterol to progesterone $(P<0 \cdot 05)$. 


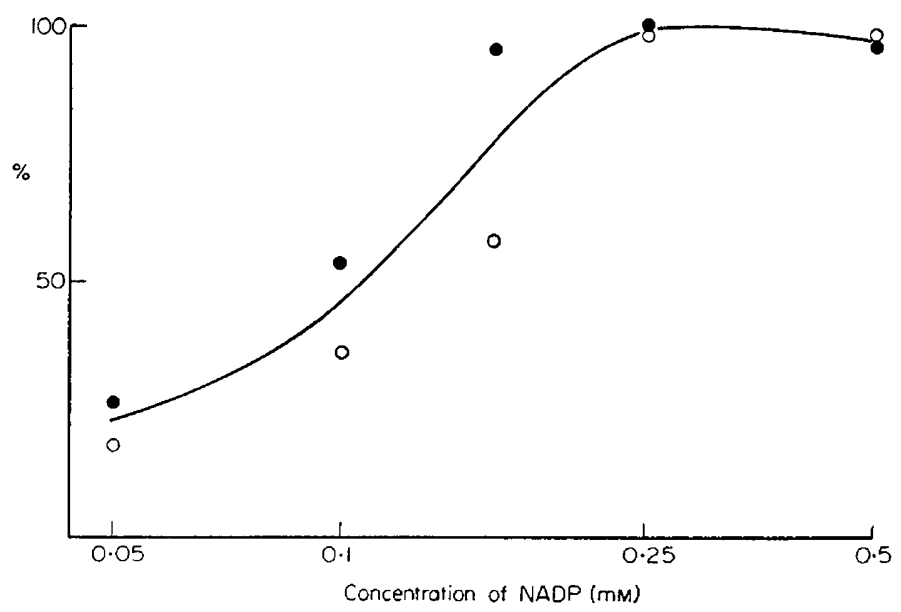

TExT-FIG. 1. Effect of NADP on the synthesis of $\left[{ }^{3} \mathrm{H}\right]$ progesterone from $\left[{ }^{3} \mathrm{H}\right]$ cholesterol by human placenta in the presence of glucose-6-phosphate $(4 \mathrm{mM})$. Two experiments, represented by open and closed circles, were carried out, with different placentae. Results are the means of duplicate determinations, expressed as percentages of the maximum synthesis in each experiment.

From the results of this investigation, it would appear that the synthesis of progesterone by the human placenta in vitro is not affected by gonadotrophic hormones or by prostaglandins found in the maternal blood and amniotic fluid.

Agents which have been shown to stimulate placental adenyl cyclase in vitro were also without effect on progesterone formation. The diminished production

Table 2. Effects of hormones, prostaglandins and cyclic-AMP on the synthesis of $\left[{ }^{3} \mathrm{H}\right]$ progesterone from $\left[{ }^{3} \mathrm{H}\right]$ cholesterol by human placenta in vitro

\begin{tabular}{|c|c|c|c|}
\hline Experiment & $\begin{array}{c}\text { Concentration of } \\
\mathcal{N} A D P(m \mathrm{M})\end{array}$ & Additions & $\begin{array}{l}{\left[{ }^{3} \mathrm{H}\right] \text { progesterone formed }} \\
\quad(d / \min / g \text { tissue } / h r) \\
\quad \text { Mean } \pm \text { S.E. }(\mathrm{n})\end{array}$ \\
\hline 1 & 0.65 & $\begin{array}{l}\text { None } \\
\text { HCG, } 10 \text { i.u./ml } \\
\text { Dibutyryl cyclic-AMP, } 2.5 \mathrm{mM}\end{array}$ & $\begin{array}{l}24,012 \pm 312(3) \\
22,353 \pm 2687(3) \\
23,642 \pm 2220(3)\end{array}$ \\
\hline 2 & 0.65 & $\begin{array}{l}\text { None } \\
\text { PGF }_{2 \alpha}, 2.82 \times 10^{-5} \mathrm{M}\end{array}$ & $\begin{array}{r}10,143 \pm 732(5) \\
8664 \pm 945(5)\end{array}$ \\
\hline 3 & 0.65 & $\begin{array}{l}\text { None } \\
\text { Vasopressin, } \uparrow 200 \mathrm{mU} / \mathrm{ml}\end{array}$ & $\begin{array}{l}33,078 \pm 1809(5) \\
33,844 \pm 1274(5)\end{array}$ \\
\hline 4 & 0.25 & $\begin{array}{l}\text { None } \\
\text { HCG, } 25 \text { i.u. } / \mathrm{ml} \\
\text { LTH, } 20 \mu \mathrm{g} / \mathrm{ml} \\
\text { Adrenaline, } 10^{-4} \mathrm{M}\end{array}$ & $\begin{array}{l}49,712 \pm 9712(3) \\
53,186 \pm 2972(3) \\
44,286 \pm 3141(3) \\
51,899 \pm 3723(3)\end{array}$ \\
\hline 5 & 0.25 & $\begin{array}{l}\text { None } \\
\text { PGF }_{2 a}, 2.82 \times 10^{-5} \mathrm{M} \\
\text { PGEE }_{1}, 2.82 \times 10^{-5} \mathrm{M} \\
\text { Cyclic-AMP, } 5 \mathrm{mM}+\text { theophylline, } 10 \mathrm{mM}\end{array}$ & $\begin{array}{l}51,371 \pm 12912(3) \\
54,834 \pm 11842(3) \\
48,515 \pm 5859(3) \\
10,556 \pm 3799(3)\end{array}$ \\
\hline
\end{tabular}

Incubations were carried out for $1 \mathrm{hr}$ (Exps 3 to 5) or $2 \mathrm{hr}$ (Exps 1 and 2). Values are corrected for losses during the extraction procedure, as measured by recovery of non-radioactive progesterone added at the end of incubation.

$* P<0.05$, Student's $t$ test. $\quad \dagger$ Pitressin; Parke, Davis and Co. 
of $\left[{ }^{3} \mathrm{H}\right]$ progesterone in the presence of cyclic-AMP was probably due to inhibition of the conversion of pregnenolone to progesterone, as has been shown in the guinea-pig placenta (Bedwani \& Marley, 1971) and other steroidogenic tissues (Koritz, Yun \& Ferguson, 1968; Sulimovici \& Boyd, 1969).

Plasma progesterone levels in early pregnancy can be elevated by infusions of vasopressin (Fylling, 1971) or by cervical dilatation, which is believed to stimulate the release of posterior pituitary hormones (Fylling \& Norman, 1970). The present results suggest that this effect of vasopressin is not due to direct stimulation of placental steroidogenesis. It should be noted, however, that the experiments reported here were carried out on placentae obtained after delivery, which may differ from pre-term placentae in their sensitivity to hormones. Another consideration is that the response of the placenta to hormones in vitro might differ from its response in vivo.

Both HCG and LH have been shown to stimulate the aromatization of testosterone to oestrogenic hormones by the human placenta perfused in vitro, an effect which is mimicked by cyclic-AMP (Cedard, Alsat, Urtasun \& Varangot, 1970). It is possible that the production of oestrogens by the placenta is controlled by gonadotrophic hormones, whilst the synthesis of progesterone is not regulated hormonally but by feedback control mediated by its biosynthetic intermediates and metabolic products (Wiener \& Friedlander, 1971).

I thank the National Institutes of Health, U.S.A., for a gift of LTH (NIHP-S9), Dr J. E. Pike of the Upjohn Company, Kalamazoo, Michigan, for supplies of prostaglandins $E_{1}$ and $F_{2 \alpha}$, and Boots Ltd for a sample of theophylline. Placentae were obtained through the staff of the Maternity Hospital, Mill Road, Cambridge, and I gratefully acknowledge their help.

\section{REFERENGES}

BEDWANi, J. R. \& MARLEY, P. B. (1971) Effect of ovariectomy and of various hormones on the synthesis of progesterone by the guinea-pig placenta in vitro. J. Reprod. Fert. 26, 343.

Cedard, L., Alsat, E., Urtasun, M.-J. \& Varangor, J. (1970) Studies on the mode of action of luteinizing hormone and chorionic gonadotropin on estrogenic biosynthesis and glycogenolysis by human placenta perfused in vitro. Steroids, 16, 361.

Diczpalusy, E. (1969) Steroid metabolism in the human foeto-placental unit. Acta endocr., Copenh. 61, 649.

FyLLING, P. (1971) Vasopressin-induced increase in peripheral plasma progesterone levels during early human pregnancy. Acta endocr., Copenh. 66, 273.

Fylling, P. \& Norman, N. (1970) Progesterone and human chorionic gonadotrophin (HGG) levels in plasma during dilation of the uterine cervix in early human pregnancy. Acta endocr., Copenh. 65, 293.

KARIM, S. M. M. (1968) Appearance of prostaglandin $\mathrm{F}_{2 \alpha}$ in human blood during labour. Br. med. $\mathcal{F}$. iv, 618.

Karim, S. M. M. \& Devin, J. (1967) Prostaglandin content of amniotic fluid during pregnancy and labour. 7. Obstet. Gynaec. Br. Commonw. 74, 230.

Kartm, S. M. M., Trussell, R. R., Hillier, K. \& Patel, R. C. (1969) Induction of labour with prostaglandin $\mathrm{F}_{2 a}$. . 7. Obstet. Gynaec. Br. Commonw. 76, 769.

Kormz, S. B., YUN, J. \& Ferguson, J. J., JR (1968) Inhibition of adrenal progesterone biosynthesis by 3',5'-cyclic AMP. Endocrinology, 82, 620.

Kuehl, F. A., Jr, Humes, J. L., Tarnoff, J., Cirillo, V. J. \& Ham, E. A. (1970) Prostaglandin receptor site: evidence for an essential role in the action of luteinizing hormone. Science, $\mathcal{N} . \Upsilon$. $169,883$.

SAtoh, K. \& Ryan, K. J. (1971) Adenyl cyclase in the human placenta. Biochim. biophys. Acta, 244, 618. 
SAtOH, K. \& Ryan, K. J. (1972) Prostaglandins and their effects on human placental adenyl cyclase. 7. clin. Invest. 51, 456.

Speroff, L. \& RAMwell, P. W. (1970) Prostaglandin stimulation of in vitro progesterone synthesis. $\mathcal{J}$. clin. Endocr. Metab. 30, 345.

Sulimovici, S. \& Boyd, G. S. (1969) The $\Delta^{5}-3 \beta$-hydroxysteroid dehydrogenase of rat ovarian tissue. The effect of adenosine 3',5'-cyclic-monophosphoric acid. Eur. 7. Biochem. 7, 549.

WIENER, M. \& FRIEDLANDER, R. L. (1971) Abnormal progesterone synthesis in placental tissue from a spontaneous abortion. Am. F. Obstet. Gynec. 111, 942. 